\title{
Neobenedenia melleni (Monogenea: Capsalidae) in ornamental reef fish imported to Brazil
}

\author{
Neobenedenia melleni (Monogenea: Capsalidae) em peixes ornamentais de recife importados para o Brasil \\ Pedro Henrique Magalhães Cardoso ${ }^{1 *}$; Simone de Carvalho Balian ${ }^{1}$; Herbert Sousa Soares ${ }^{1}$; Karen Roberta Tancredo ${ }^{2}$; \\ Maurício Laterça Martins ${ }^{2}$
}

\begin{abstract}
${ }^{1}$ Departamento de Medicina Veterinária Preventiva e Saúde Animal, Faculdade de Medicina Veterinária e Zootecnia, Universidade de São Paulo - USP, São Paulo, SP, Brasil

${ }^{2}$ Laboratório AQUOS - Sanidade de Organismos Aquáticos, Departamento de Aquicultura, Universidade Federal de Santa Catarina - UFSC, Florianópolis, SC, Brasil
\end{abstract}

Received June 21, 2018

Accepted September 27, 2018

\begin{abstract}
The capsalid monogenean Neobenedenia melleni is known as a lethal pathogen for captured marine teleost ornamental fish, if left untreated. This study reports the occurrence of $N$. melleni parasitizing four species of ornamental reef fish imported into Brazil and maintained in quarantine: Arabian angelfish (Pomacanthus asfur), yellowbar angelfish (Pomacanthus maculosus), regal angelfish (Pygoplites diacanthus), and bluecheek butterflyfish (Chaetodon semilarvatus). Ten days after the beginning of quarantine, some fish showed behavioral alterations, such as irritability, and corneal opacity, which were rapidly diagnosed to be caused by monogenean parasites by body surface scraping. The fish from the same batch were treated with two applications of $2 \mathrm{mg} \mathrm{L}^{-1}$ praziquantel each at an interval of four days. Seven days after the first treatment, the mucus surface of the fish was re-examined, which did not reveal the parasites presence being delivered for commercialization.
\end{abstract}

Keywords: Marine ornamental fish, Pomacanthus, Pygoplites, Chaetodon, Neobenedenia melleni, transboundary disease.

\section{Resumo}

Neobenedenia melleni é conhecido como um parasito letal para peixes teleósteos ornamentais marinhos capturados se não tratado. Este estudo relata a ocorrência de $N$. melleni parasitando quatro espécies de peixes ornamentais importados para o Brazil: Arabian angelfish (Pomacanthus asfur), yellowbar angelfish (Pomacanthus maculosus), regal angelfish (Pygoplites diacanthus) e bluecheek butterflyfish (Chaetodon semilarvatus). Dez dias depois do início da quarentena, foram observados irritabilidade e opacidade na córnea dos peixes que, foram diagnosticadas com N. melleni na superfície corporal. Todos os peixes foram tratados com duas aplicaçôes de praziquantel $2 \mathrm{mg} \mathrm{L}^{-1} \mathrm{em}$ intervalo de quatro dias. Sete dias após o início do tratamento, um novo exame parasitológico foi realizado o qual náo revelou a presença dos parasitos, sendo liberados para comercialização.

Palavras-chave: Peixes ornamentais marinhos, Pomacanthus, Pygoplites, Chaetodon, Neobenedenia melleni, doença transfronteiriça.

\section{Introduction}

Ornamental fish trade is characterized by the aggregation of fish species from several countries. More than 1,450 marine fish species are commercialized as ornamental fish and approximately $90 \%$ of them are captured from the nature. Most of the pathogenic

\footnotetext{
*Corresponding author: Pedro Henrique Magalhães Cardoso. Departamento de Medicina Veterinária Preventiva e Saúde Animal, Faculdade de Medicina Veterinária e Zootecnia, Universidade de São Paulo - USP, Rua Professor Orlando Marques Paiva, 87, CEP 05508-270, São Paulo, SP, Brasil. e-mail: pedrohenriquemedvet@usp.br
}

agents are metazoans, protozoans, bacteria, and viruses, which may be transferred together with the translocated animals, which might lead to disease outbreaks. In order to minimize transboundary disease dissemination, the governmental authorities must require quarantine measures to be applied to the imported product (WHITTINGTON \& CHONG, 2007).

Monogeneans are Platyhelminthes parasites normally found in fish and lower invertebrates. Among monogenean families, four are frequently diagnosed in farmed fish as Gyrodactylidae, Dactylogyridae, Ancyrocephalidae, and Capsalidae. Capsalids are 
found to parasitize the skin and eyes of marine fish and occasionally brackish water fish. Some of them, such as Neobenedenia spp. and Benedenia spp., can cause chronic damage in fish maintained in marine aquariums and are difficult to eradicate when disseminated (REED et al., 2012).

Neobenedenia melleni (MacCallum, 1927) is a lethal pathogen for the captured marine fish after transfer to the aquarium (DEVENEY et al., 2001). It presents worldwide distribution and low host specificity (SILVA et al., 2014). It has been found in more than 100 teleost fish of 30 families including several Tropical reef fish families, such as Acanthuridae, Ariidae, Balistidae, Diodontidae, Holocentridae, Carangidae, Chaetodontidae, Malacanthidae, Lutjanidae, Labridae, Lobotidae, Ostraciidae, Pomadasyidae, Percichthyidae, Pomatomidae, Psettidae, Scatophagidae, Serranidae, Sparidae, and Triglidae (BULLARD et al., 2003; THONEY \& HARGIS, 1991; WHITTINGTON \& HORTON, 1996).

Neobenedenia melleni feeds on mucus and epithelial cells of the host, leading to behavioral alterations, including flashing on the rocks and substrates, which might cause lesions and secondary infection. Parasitized fish normally shows corneal and skin lesions, blindness, weakness, anorexia, hemorrhages, mucus hypersecretion, and death due to secondary infections if not treated (KERBER et al., 2011).

The present study reports the occurrence of $N$. mellen $i$ after a stress period of transport of four ornamental reef fish imported into Brazil, Arabian angelfish (Pomacanthus asfur), yellowbar angelfish (Pomacanthus maculosus), regal angelfish (Pygoplites diacanthus) and bluecheek butterflyfish (Chaetodon semilarvatus).

\section{Materials and Methods}

The ornamental reef fish $P$. asfur $(n=6)$, weighing approximately $80 \mathrm{~g}$ and approximately $10 \mathrm{~cm}$ long, $P$. maculosus $(n=5)$, weighing approximately $80 \mathrm{~g}$ and approximately $10 \mathrm{~cm}$ long, $P$. diacanthus $(\mathrm{n}=5)$ weighing approximately $120 \mathrm{~g}$ and approximately $15 \mathrm{~cm}$ long, and $C$. semilarvatus $(n=5)$ weighing approximately $80 \mathrm{~g}$ and approximately $8 \mathrm{~cm}$ long were obtained from a quarantine after imported to São Paulo, Southeastern Brazil. The fish were originally captured from the natural environment in Djibouti $\left(11^{\circ} 35^{\prime} 20^{\prime \prime} \mathrm{N} ; 43^{\circ} 8^{\prime} 42^{\prime \prime} \mathrm{E}\right)$, Red Sea, Indian Ocean, and maintained in aquaria with a recirculation system of $0.6 \mathrm{~m}^{3}$, and fed five times a day with commercial diet (Germany, Tetra ${ }^{\circledR}$ Marine flakes and granules) and clams. Water quality parameters were measured daily and maintained at: temperature of $26^{\circ} \mathrm{C}$, salinity of $29 \mathrm{mg} \mathrm{L}^{-1}$, dissolved oxygen content of $5 \mathrm{mg} \mathrm{L}^{-1}, \mathrm{pH}$ of 8.2, and total ammonia concentration $<0.1 \mathrm{mg} \mathrm{L}^{-1}$.

Fish arrived at the quarantine establishment with no apparent clinical signs, but 10 days after arriving, some fish $[$ P. asfur $(\mathrm{n}=3)$, $P$. maculosus $(\mathrm{n}=3), P$. diacanthus $(\mathrm{n}=1)$, and $C$. semilarvatus $(\mathrm{n}=1)$ ] began to present behavioral alterations such as flashing, skin depigmentation and corneal opacity (Figure 1). Suspecting monogenean infection, all the fish were subjected to skin scraping and after treated separately with freshwater bath at the same water temperature for $3 \mathrm{~min}$.

Thereafter, the fish were transferred to a hospital aquarium of $0.6 \mathrm{~m}^{3}$ with a water temperature of $26^{\circ} \mathrm{C}$, salinity $29 \mathrm{mg} \mathrm{L}^{-1}$, dissolved oxygen concentration $5 \mathrm{mg} \mathrm{L}^{-1}, \mathrm{pH} \mathrm{8.2,} \mathrm{and} \mathrm{total}$ ammonia concentration $<0.1 \mathrm{mg} \mathrm{L}^{-1}$, with no activate carbon and biological filter, to be treated by two long-term bathes of $24 \mathrm{~h}$ with $1.2 \mathrm{~g}$ of praziquantel (diluted previously in $20 \mathrm{~mL}$ $70 \%$ alcohol) at four-day intervals according to Noga (2010). Three days after the second treatment bath, the fish were bathed in freshwater to verify the presence of the parasite. Twenty-four hours after praziquantel application, $300 \mathrm{~g}$ of activated charcoal $\mathrm{Hw}^{\circledR}$ was used to remove the praziquantel residues added. The fish were fed five times a day with commercial diet (Germany Tetra ${ }^{\circledR}$ Marine flakes and granules) and clams in the hospital aquarium.

\section{Morphological identification}

After freshwater bath, the adult's parasites falling off were collected with a thin sieve of $350 \mu \mathrm{m}$ mesh, bathed in heated water at $56^{\circ} \mathrm{C}$ for laxness, and fixed in $70 \%$ alcohol for identification. In the laboratory, they were washed in distilled water in a Petri dish, and mounted in Hoyer's following the routine procedures (KRITSKY et al., 1995) for observing the sclerotized structures.

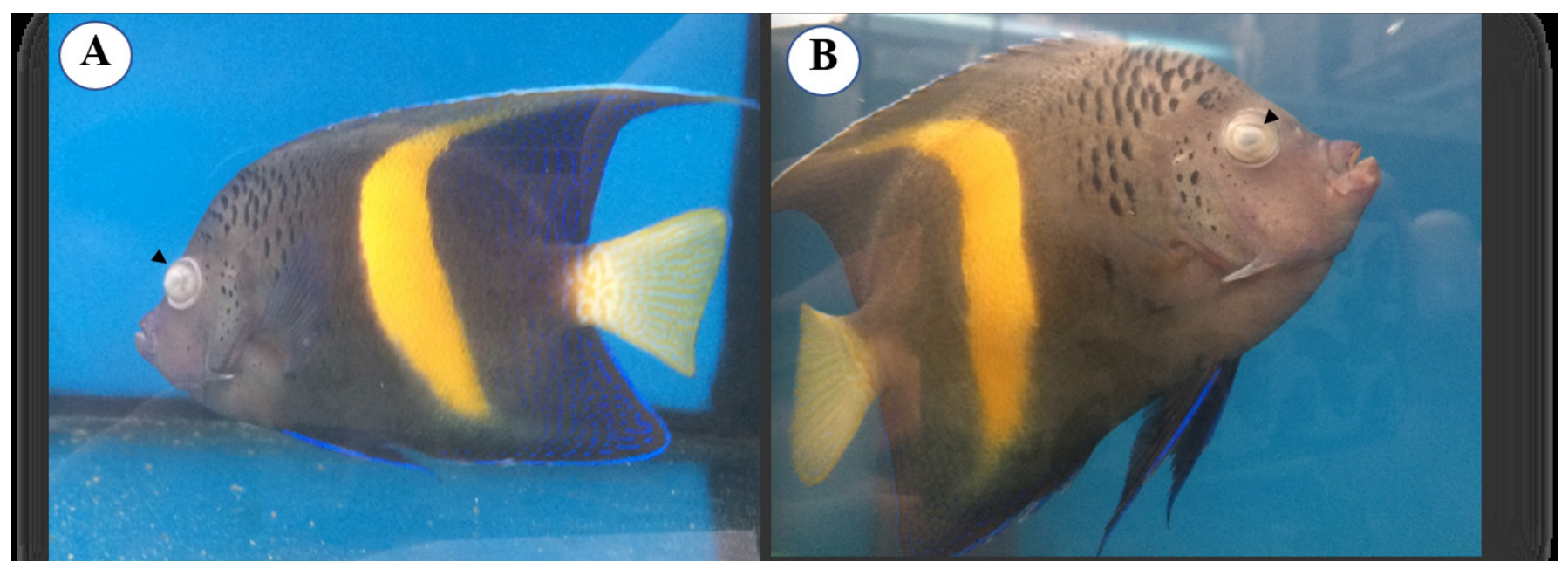

Figure 1. Pomacanthus asfur with corneal opacity caused by Neobenedenia melleni. 
Photomicrographs were obtained in a differential interference contrast (DIC) microscope (Zeiss Axio Imager A2), and the morphological criteria used followed Whittington \& Horton (1996). Parasitological descriptors such as prevalence, mean intensity, and mean abundance followed Bush et al. (1997).

\section{Results}

The ectoparasite present on the body surface and eyes was identified as the monogenean N. melleni (Maccallum, 1927) Yamaguti, 1963 (Capsalidae) (Figure 2). They fall off in the freshwater bath. The prevalence of $N$. melleni was $66.6 \%$ in P. asfur, $60 \%$ in P. maculosus, $40 \%$ in $P$. diacanthus, and $40 \%$ in $C$. semilarvatus. The highest mean intensity of infestation was

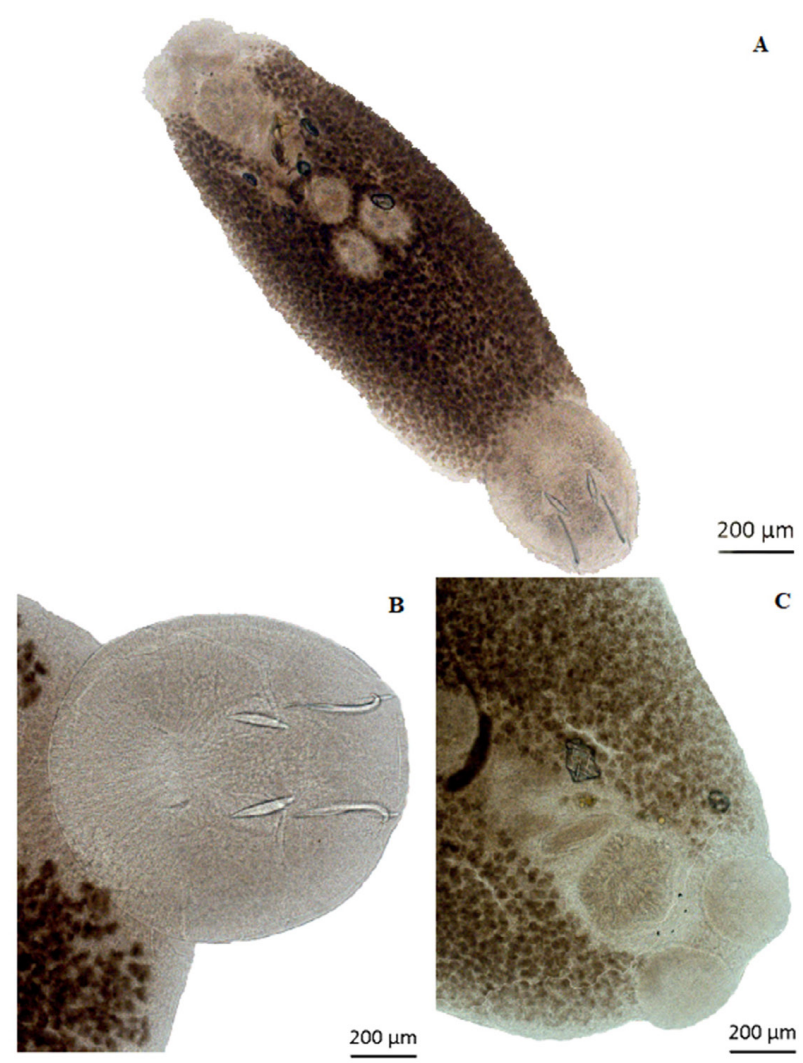

Figure 2. Light photomicrographs of sclerities parts of Neobenedenia melleni MacCallum, 1927 (Monogenea: Capsalidae), from marine ornamental fish collected in São Paulo, Brazil. (A) adult specimen; (B) haptor; (C) anterior part. found in P. maculosus, and the lowest was found in $P$. diacanthus. In addition, the highest mean abundance occurred in $P$. asfur, whereas the lowest occurred in $P$. diacanthus (Table 1). All the treated fish that presented corneal lesions recovered seven days after treatment and did not show parasites after skin scrapings. Therefore, they were delivered for commercialization.

\section{Discussion}

The earlier adoption of diagnostic and therapeutic measures with freshwater bath, followed by treatment with praziquantel, did improve the prognostic of the diseased fish of great economic value in this study. Freshwater bathing was previously performed successfully in the cage-farmed cobia, Rachycentron canadum, parasitized by $N$. melleni (MOREIRA et al., 2013). The success of prognosis is even greater when the fish are maintained under optimal water quality conditions and fed with balanced diet (CARDOSO et al., 2017).

Neobenedenia melleni has low host specificity and is responsible for significant damage to the skin and eyes, causing corneal opacity. In this study, $N$. melleni was indeed responsible for causing skin irritation and corneal opacity in P. asfur, P maculosus, P. diacanthus, and $C$. semilarvatus confirming its importance as an etiological agent. It has been found in several fish species, including reef fish (BULLARD et al., 2003; THONEY \& HARGIS, 1991; WHITTINGTON \& HORTON, 1996).

Frequently during transport, the fish are excessively handled and overcrowded in aerated bags that increase the concentration of nitrogenous substances released by fish during excretion (ammonia), leading to stressful conditions. During stress, cortisol release causes inhibition of the immune system, thereby favoring disease appearance in immunosuppressed fish (DAVIS et al., 2002)

Ornamental fish commonly have high parasite infestations or infections owing to high stocking density, and sometimes owing to inadequate water quality maintenance. In addition to the physiological alterations in these hosts, $N$. melleni has high reproduction rate in closed aquatic systems (DEVENEY et al., 2001; HOAI \& HUTSON, 2014; WHITTINGTON, 2004).

Mostly, imported fish are captured from the natural environment and bring together parasites that are not always observed during short time quarantine of seven days proposed by the government (BRASIL, 2015). In this report, the clinical signs appeared only after 10 days, and they were promptly were diagnosed and treated with praziquantel. Praziquantel is a wide-spectrum anthelmintic commonly considered safe for use in humans and domestic animals, effective, and economic. Its efficacy is higher than $80 \%$, when

Table 1. Mean values and standard deviation of parasitological indices of Neobenedenia melleni in ornamental reef fish imported from Djibuti, Red Sea, Indian Ocean.

\begin{tabular}{ccc}
\hline Fish species & Prevalence (\%) & Mean intensity \\
\hline Pomacanthus asfur & 66.66 & $6.00 \pm 3.26$ \\
Pomacanthus maculosus & 60.00 & $6.33 \pm 1.52$ \\
Pygoplites diacanthus & 40.00 & $1.5 \pm 0.70$ \\
Chaetodon semilarvatus & 40.00 & $2.5 \pm 2.12$ \\
\hline
\end{tabular}


applied at 0.7-20 $\mathrm{mg} \mathrm{L}^{-1}$ for 1-48 h (MITCHELL \& DARWISH, 2009; MORALES-SERNA et al., 2018). In this study, we used two bathes of $2 \mathrm{mg} \mathrm{L}^{-1}$ at four-day intervals and did showed high effectiveness once the parasites were removed from the fish.

Ornamental imported fish has high commercial price in the National Market once they are bought in dollars. They are subjected to high tributary load of importation and international transport, which enhance the costs of each batch of fish. In order to minimize the economic losses and mortality with parasitic diseases, and to promote fish welfare, it is necessary to take care of the fish until the fish are sold (CARDOSO et al., 2017). Appropriate quarantine period, handling by trained professionals, early diagnosis, and preventive treatment of some parasites, such as $N$. melleni, are important for maintaining the fish in aquarium and minimizing the risk of introduction of transboundary diseases.

In this report, the disease was detected early in the animals, elucidating the efficacy of the treatment, which avoided losses of fish owing to mortality. These results emphasize the importance of quarantine in aquatic animals captured from the nature and transferred to the laboratory and/or aquarium to be stored for commercialization, because the correct diagnostic in diseased fish sometimes can pass overlooked.

\section{Acknowledgements}

We thank National Council of Scientific and Technological Development (CNPq) for research grant to M.L. Martins (CNPq 305869/2014-0), for doctoral scholarship to P. H. M. Cardoso (CNPq 160855/2014-4), and William E. Furtado (AQUOS, UFSC) for parasite pictures.

\section{References}

Brasil. Ministério da Pesca e Aquicultura. Instrução Normativa n ${ }^{\circ}$ 4, de 4 de fevereiro de 2015. Diário Oficial da República Federativa do Brasil, Brasília, 9 fev. 2015.

Bullard SA, Goldstein RJ, Hocking R, Jewell J. A new geographic locality and three new host records for Neobenedenia melleni (MacCallum) (Monogenea: Capsalidae). Gulf Caribb Res 2003; 15(1): 1-4. http:// dx.doi.org/10.18785/gcr.1501.01.

Bush AO, Lafferty KD, Lotz JM, Shostak AW. Parasitology meets ecology on its own terms: Margolis et al. revisited. J Parasitol 1997; 83(4): 575583. http://dx.doi.org/10.2307/3284227. PMid:9267395.

Cardoso PHM, Balian SC, Matushima ER, Pádua SB, Martins ML. First report of scuticociliatosis caused by Uronema sp. in ornamental reef fish imported into Brazil. Rev Bras Parasitol Vet 2017; 26(4): 491-495. http:// dx.doi.org/10.1590/s1984-29612017031. PMid:28658416.

Davis KB, Griffin BR, Gray WL. Effect of handling stress on susceptibility of channel catfish Ictalurus punctatus to Ichthyophthirius multifliis and channel catfish virus infection. Aquaculture 2002; 214(1-4): 55-66. http://dx.doi.org/10.1016/S0044-8486(02)00362-9.

Deveney MR, Chisholm LA, Whittington ID. First published record of the pathogenic monogenean parasite Neobenedenia melleni (Capsalidae) from Australia. Dis Aquat Organ 2001; 46(1): 79-82. http://dx.doi. org/10.3354/dao046079. PMid:11592706.

Hoai TD, Hutson KS. Reproductive strategies of the insidious fish ectoparasite, Neobenedenia sp. (Capsalidae: Monogenea). PLoS One 2014; 10(2): e0117881. http://dx.doi.org/10.1371/journal.pone.0117881. PMid:25668188.

Kerber CE, Sanches EG, Santiago M, Luque JL. First record of Neobenedenia melleni (Monogenea: Capsalidae) in sea-farmed cobia (Rachycentron canadum) in Brazil. Rev Bras Parasitol Vet 2011; 20(4): 331-333. http:// dx.doi.org/10.1590/S1984-29612011000400013. PMid:22166389.

Kritsky DC, Boeger WA, Popazoglo F. Neotropical Monogenoidea. 22. Variation in Scleroductus species (Gyrodactylidea, Gyrodactylidae) from siluriform fishes of Southeastern Brazil. J Helminthol Soc Wash 1995; 62(1): 53-56.

Mitchell A, Darwish A. Efficacy of 6-, 12-, and 24-h Praziquantel bath treatments against Asian tapeworms Bothriocephalus acheilognathi in Grass Carp. North Am J Aquac 2009; 71(1): 30-34. http://dx.doi. org/10.1577/A07-091.1.

Morales-Serna FN, Chapa-López M, Martínez-Brown JM, Ibarra-Castro L, Medina-Guerrero RM, Fajer-Ávila EJ. Efficacy of praziquantel and a combination anthelmintic (Adecto ${ }^{\circledR}$ ) in bath treatments against Tagia ecuadori and Neobenedenia melleni (Monogenea), parasites of bullseye puffer fish. Aquaculture 2018; 492: 361-368. http://dx.doi.org/10.1016/j. aquaculture.2018.04.043.

Moreira CB, Hashimoto GSO, Rombenso AN, Candiotto FB, Martins ML, Tsuzuki MY. Outbreak of mortality among cage-reared cobia (Rachycentron canadum) associated with parasitism. Rev Bras Parasitol Vet 2013; 22(4): 588-591. http://dx.doi.org/10.1590/S1984-29612013000400021. PMid:24473886.

Noga EJ. Fish disease: diagnosis and treatment. 2nd ed. Iowa: Willey Blackwell; 2010.

Reed P, Francis-Floyd R, Klinger R. Monogenean parasites of fish. Gainesville: University of Florida IFAS Extension. 2012.

Silva FC, Leite JR, Hostim-Silva M, Valença AR, Sanches EG. First record of Neobenedenia "melleni" - like species (Monogenea: Capsalidae) in Goliath grouper Epinephelus itajara in Brazil. Rev Bras Parasitol Vet 2014; 23(1): 248-250. http://dx.doi.org/10.1590/S1984-29612014025. PMid:25054507.

Thoney DA, Hargis WJ Jr. Monogenea (platyhelminthes) as hazards for fish in confinement. Annu Rev Fish Dis 1991; 1: 133-153. http://dx.doi. org/10.1016/0959-8030(91)90027-H.

Whittington ID, Horton MA. A revision of Neobenedenia Yamaguti, 1963 (Monogenea: Capsalidae) including a redescription of N. melleni (MacCallum, 1927) Yamaguti, 1963. J Nat Hist 1996; 30(8): 1113-1156. http://dx.doi.org/10.1080/00222939600770611.

Whittington ID. The capsalidae (Monogenea: Monopisthocotylea): a review of diversity, classification and phylogeny with a note about species complexes. Folia Parasitol (Praha) 2004; 51(2-3): 109-122. http://dx.doi. org/10.14411/fp.2004.016. PMid:15357390.

Whittington RJ, Chong R. Global trade in ornamental fish from an Australian perspective: the case for revised import risk analysis and management strategies. Prev Vet Med 2007; 81(1-3): 92-116. http:// dx.doi.org/10.1016/j.prevetmed.2007.04.007. PMid:17485126. 